\title{
Why is Art Met with Disbelief? It's Too Much like Magic
}

\section{Jan Verwoert}

\section{I: Demands?}

Art is jinxed. And the curse is double. Like inexorcisable demons, two questions follow it around, no matter how hard we try to ward them off. 'What is it good for?' some inquire, while others demand to know, 'What does it represent?' So art gets wrenched between two impatient requests: to have its use value revealed and its meaning declared. In effect, the power of status is at work in both curses. Status is a restless devil. It wants to be identified and have its name spelled out. It won't rest before it is. In surprising unison the working and upper class are eager to oblige: yes, the status of art must be identified, as soon as possible, and at all cost.

Class perspectives only differ in terms of the standards applied to measure status. Even if, in the 1970s, many workers moved on up from factory halls to office floors, their world view mostly remained rooted in the traditional utilitarian mindset: a thing only qualifies as real-and its maker as respectable - if its making can be shown to serve a recognisable purpose. If not, it's deemed a queer trade and waste of money that an honest man cannot afford to be seen indulging in. People with an interest in being recognised as upper class will wish to associate themselves with the notion of being 'cultured' and hence consider buying or funding art. Yet, only if its status is widely confirmed. While the working man will want to know what the art costs (invariably too much!), a person with high disposable income will need to see what it's worth (in five years time).

It's a farce. But we're in it. And escaping the impasse isn't easy. Stock-in-trade arguments for defending the value of art 
for art's sake won't hold up to interrogation. Art: autonomous? No. We can't deny that artistic survival depends on material interests and symbolic transfers brokered in the status economy. Art: a path to 'higher values'? A difficult point to argue when making art is what you do on a daily basis, so the utterly mundane nature of this activity is your first-hand experience. Why pretend it was otherwise? The trouble is you can't bank on it either. For, even though it's work to you, it doesn't mean that most people wouldn't much rather look upon it as a form of being idle. When grand claims to the exceptional metaphysical status of artistic labour have become a thing of the past, and chances of it ever qualifying as regular wage labour seem remote (and hardly attractive), our position isn't exactly easy.

Changing someone's idea of status and value is difficult. Because they tend to defend this idea as if their life depended on it. In some sense it actually does. For people will have made existential decisions and given their lives a direction based on standards of status and value that seemed desirable, or without alternative, at the time. Art then presents a potential threat, as it shows that there are indeed alternatives to the standards on which their existences are built. It's a classic among the top twenty conversations from hell: getting cross-examined over Sunday dinner by prospective in-laws who, with increasing persistence, try to elicit a confession from you to confirm their suspicion that 1. art is a big fraud ('I could paint something like that!') and 2. modern artists are pretentious impostors who con people out of their money by selling them stuff of no real value. In such a situation, defending art as a realm in which value can be freely negotiated seems hardly worth trying. Arguments will neither change the residual beliefs, nor will they relieve the fears that are at stake when art is met with disbelief.

It may sound like truisms out of a self-help book. But when the challenge is to stand up and not give in to the pressure imposed by a status economy of bad faith, the problem undeniably also has a spiritual dimension: In what spirit then are we to meet those who demand art's status to be declared and its meaning to be revealed?

To begin with, what would be needed is something akin to an exorcism. Arguably, what gives the demand for art's 
status to declare its immense power is that it's usually already deeply internalised by those, us, who are habitually exposed to it. We take it to heart. Knowing that, before long, we will have to absolve yet another ceremony of justification, we prepare ourselves, arrange our defenses and, worse still, potentially go as far as to (re)organise our practices according to whatever new paradigm currently appears to be imbued with the magical power to bestow instant legitimacy on what we do. (From today's book of incantations we recommend 'research-based art' or 'art as a form of knowledge production'.) It's a game we can only lose, because the rules are written by others. The point is to cast the demon of status out, so that next time you meet the demon his voice is not also coming from the back of your own head, but clearly only from the person confronting you, articulating their beliefs and fears, not yours. This is not to suggest that there would or should be a space of uncompromised autonomy (aka naivity/genius) in which we could want to retreat. The demand for art's status to be declared will always be there. What makes all the difference, however, is whether you engage it on its terms - or in a spirit of subtle defiance nourished on other experiences and perspectives. So where to look for these?

\section{II: Rhythm and rhyme!}

The point is to relate. Wildly. To people, things, ideas, visible and invisible, sublime and mundane phenomena and occurences of all kinds, that may or may not even be proven to exist by positive science, but nonetheless surround us everyday, like nature and urban life do. 'Wildly' means: not in accordance with a preset standards of equivalency, the rule of the tit for tat, that governs economical thinking and permits status/value to be quantified, taxed and compared. What incites the urge to dodge quantification and relate wildly is not only rebelliousness. It's a deeply environmental concern. Environments are more than just economies. What matters in environments, instead of values and status, is qualities and states. Qualities such as: small rather than big, wet rather than dry, silver rather than blue ... States like: liquid rather than frozen or vaporous, animated rather than inanimate, thinking rather than unthinking ... 
What does it mean to relate to such environmental qualities? It's not even clear whether it means to act. Getting soaked in the rain is not an action. But it's definitely a state experienced as a result of entering (into a relation to) an environment. To paint one particular colour or draw a specific shape would no doubt seem to pass as an action. But getting a sense for the quality of this colour and shape, for its reason to be and remain in the mix (rather than become erased or overpainted) has fairly little to do with a logic of purposeful action. Rather, it's a longterm process of attuning oneself to the decisive relations and tensions between the qualities and states within an environment, as much as within the work. This is not just some consideration of the laws of more or less tasteful composition. Rather, it's a sense for what does, or precisely doesn't, rhyme or resonate.

Rhyme and resonance can neither be declared nor quantified. Rhyme is not a status something or someone could acquire. It's an environmental relation between elements with a certain chemistry between them. Rhyme is a mimetic quality: a characteristic of two words, shapes, sounds, colours (and so on) that exist in the state of being somehow alike. That the line 'To be with you' rhymes with 'Waiting on a line of greens and blues' isn't premised on them sharing the same status, neither semantically nor grammatically. Strictly speaking, it doesn't make an ounce of sense that the two lines should resonate with each other. But they do. And this is just one given example. There are myriad more, naturally.

Finding a rhyme or rhythm that sticks, however, is not just a matter of matching elements from a given set of parts. It's much rather a recalibration of relations within a whole. A rhythm that works creates a connection between the sound a thing (drum) makes when hit and the desire to move your body. Likewise, a rhyme (if it's any good) triggers the desire to mimic its workings, to rhyme the rhyme, repeat, learn and intonate it, to sing along. When they work, rhythm and rhyme not only constitute a relation between beats and words, but very much also an overall force-field, within which energies are accumulated and given a particular quality and direction. A room full of people dancing or a child crooning along to a nursery rhyme are two examples of mimetic relations in 
the state of being activated or animated. In each case the momentum of the activated or animated relation shapes and transforms the mood - that is, the very condition for experiencing - a given environment. A space in which people sit and work is not the same space as one in which people drink and dance together, even if, physically, it may be the same room.

The emphasis here, however, is not necessarily on 'together'. The element of correspondance which generates the energy at the heart of the mimetic relation is precisely not an identity relation. 'Blue' is not 'You'. They are two different words. The Beat is not the dance move. One is made by a drum. The other by a hip. Still they correspond. Correspondence in a state of non-identity allows for a transformation of realities that no one reality principle or symbolic economy based on laws of equivalency can contain. Take a traditional Italian nursery rhyme for example: ${ }^{1}$
Ambarabà ciccì coccò
Tre civette sul comò
Che facevano l'amore
Con la figlia del dottore
Il dottore si ammalò
E la figlia si sposò
Ambarabà ciccì coccò!

Under the sign and spell of the (purely phonetic) Ambarabà cicci coccò, the calculus of quid pro quo is replaced by the logic of rhyme, assonance and rythm. Following this new logic, reality reconfigures itself along a skewed axis: three owls on a dresser make love to the doctor's daughter, the doctor gets ill and the daughter gets herself married. Under the spell of the Ambarabà ciccì coccò, animals, furniture and family relations shift into a new constellation in which per- and in- versions of all kinds take place. In the world of mimetic power, healing is the art of curing like with like. It's risky. For relations can flip. Then the fire you start to fight fire, is the fire than comes to burn you. Like consumes like. The shaman is caught in his own spell. The doctor gets ill. As happens in the lullaby. Scary! But exhilarating too! Because in a world where laws of identity and difference apply no longer, intercourse with nightbirds 
is legal and, although it may cast a strange light on the latter, doesn't prevent marriage.

Now, picture the situation in which the rhyme is sung and repeated over and over by parent or nurse and child and you see a pathway open into a magical world. To perform the rhyme together is to enter and inhabit this world. You are in it when you sing it. You experience how the world governed by the symbolic status economy of the quid pro quo-where this means this and that means that - fades away and transitions into the state of ciccì coccò where all things have different qualities: The colours of the dark vowels ò and e and the sharp rhythm of the double consonants cc and tt evoke-and in the course of their very evocation create - the shades and contours of the world of owls, dressers, doctors and daughters. Given that the nursery rhyme will also be sung as a lullaby, the magical world of rhythm and rhyme here also prefigures the reality of the dream into which it builds a bridge, as the child is lulled to sleep by the rythmical return of resonant words looping back onto the magic formula Ambarabà ciccì coccò.

\section{III: Environmental, not economical}

It's not a prerogative of art to effect this transition into the magical world of mimesis. A simple lullaby can do the trick. At the same time, however, art fundamentally continues to be associated with the magic of mimesis: in terms of the classic notion of drawing or painting after nature, or 'taking someone's likeness'-but also very much in terms of the qualities of rhythm and rhyme, a-, dis-, con- and re- sonance which make up the material magic of the sympathetic attraction or antipathic friction we (misleadingly) refer to as principles of composition. A philosophy of the Ambarabà ciccì coccò could offer a much more adequate way to describe what forces are at play in art that yields to the magic of its own material workings.

The crux, however, is that the Ambarabà ciccì coccò can't actually be appropriated as a concept without its secret and spirit being lost in that act. Asserted as a principle 'as such' the ciccì coccò will turn into a display of mere childishness, or madness. Mimetic magic is a relational force. It only comes into effect when it can resonate with other things, people, 
qualities and states within an environment. This holds true even and especially now that, in modern urban artistic contexts, we're no longer dealing with tribal magic proper, but instead with whatever residual element of that magic has survived in nursery rhymes and the 'compositional' material dimension of art practice. It's all in the interplay of relations. This is why, magical as it may be, the element of the mimetic must frustrate attempts to use it as an argument in defense of art's status or significance. 'What is art good for?' - 'Well, it's magic.' - 'How so? Prove it! Seeing is believing!' In an environment where no sympathy prevails, magic never works, only the most obvious tricks do.

Organised religions authorise a priest to make aspiring believers feel it must be their fault if they don't feel or see anything during a religious service. No doubt, there are still artists around who try, and sometimes succeed, in (re)creating the same conditions by instituting their own religions of devoted disciples, supportive critics and so on, so as to give them the right to condemn disbelievers as stupid or evil. It's life in a lie. And paranoia is the price the gods of their own church tend to pay when they fear the outside world to be conspiring against the doctrine of their greatness. So we know the securities cults offer are false. And, lest we forget, religions, for times immemorial, have primarily served as institutions for enforcing unjust power structures. Hence there's no need to be nostalgic for the cultic. The true challenge is to engage the forces, qualities and states of the Ambarabà ciccì coccò without institutional backup: without any guarantee that the magic of mimesis will work - for everyone, and more than once, that is, on the next day too, if it worked the night before. When there's no priest to watch over the performance of the magic rite and ensure that the audience feels sufficiently awestruck (or guilty for not feeling anything), the attempt to bring your art to life and summon the spirit of your ideas in front of an audience can always misfire. And the embarrassment is yours. You stand exposed as a failed conjurer. But this is how it is, and how it can only be, when we reject the false securities of religions. The possibility of total embarrassment is built into the very condition of practising the magic of the mimetic (as art) outside the cult. So what can we do? But embrace it! 
It's an insight that offers little comfort, but may still inform the spirit in which to meet the demand for art's status to be declared. The intimate tie that connects art to the magic of the mimetic is precisely what won't permit its status to be unambiguously identified. In a profound manner, art is about relations rather than representations, about qualities and states, rather than status. But this in itself is no secret. It's probably fair to assume that so much pressure is put on art precisely because people sense that they deal with a cultural force here - mimesis - which, although present and at play amid everyday culture, from nursery rhymes to radio hits, still remains fundamentally alien to the mindset of modern economic rationality. ${ }^{2}$

The irony is that the mimetic element (and art as its token advocate) survives in such an awkward position amid modern economical representational and techno-scientific culture, not because it is altogether alien, but because, arguably, it's the very source from which modern culture once sprang. Science emerged from alchemy and gradually came to substitute magic as the most prevalent technique for relating to the natural world. Likewise, the economical operations of assigning values to things to trade them, arguably stem from ceremonies of consecration and gift giving in which symbolic transactions are inseparable from the larger religious or tribal set of beliefs and rules in accordance with which they are enacted. In this sense, modern economic and techno-scientific culture only seeks to disavow, deny and repress the connection to its very own origins. Since art is a visible remainder and reminder of this connection, it gets a lot of flak to catch, by proxy. In meeting art with disbelief, the modern world expunges the unmanageable truth that its very own operating principles originated in magic rites.

And, in effect, it makes no difference if art is dismissed as irrational or fetishised as a source of magical illuminations on Sunday visits to the Met. 'The Magical' is a pedestal from which art can only fall, when the notion that creators of art are higher beings is propagated as a justification for distinguishing 'high' from 'popular' culture. Isolated, however, from the world of mundane relations in which alone it could actually activate its magic (like the lullaby does), a revered 
masterpiece can only ever disappoint. Invariably, the Van Gogh one religiously queues up to see will leave no impression, as the high expectations to have it deliver an instant epiphany prevents it from having any effect at all.

The bottom line, if there is any, probably is that, in art, we are unofficial heirs to the powers of mimesis. But, even if we agree to take on this heritage it will never be exclusively ours. There is no way to own mimesis. It's everywhere anyhow, alive and at play in every rhythm and rhyme that works and all things or works we perceive as animated. Which, on the other hand, is also a way of saying that art is never isolated, in the first place. It finds itself connected on all sides into the circuits of mimetic energy loops, from radio hits to bird calls. Urban rituals and natural phenomena play the same role here. They set the rhythms and moods to which a practice may want to attune itself (con-, as-, dis- or re- sonantly) in the course of activating the qualities and states that animate an environment as an environment. Relational at heart, such a practice of animation will perhaps never acquire a clearly distinguishable status in and for itself, the less the more it resonates qualitatively with its surroundings. Yet, at the same time, it will, most vividly, give you an idea why art could be considered a truly environmental practice.

\section{Notes}

1 I thank Federica Bueti for introducing me to the rhyme.

2 Here, I paraphrase a thought developed in T. W. Adorno, Aesthetic Theory

(Minneapolis: University of Minessota Press, 1997), 118-20. 